УДК 634.25:631.527:631.529(477.75)

(C) 2013

Шоферистов Е. П., доктор биологических наук, Бунчук Е. И., аспирант *

Никитский ботанический сад - Национальный научный центр НААНУ

\title{
ПЕРСИК КРАСНОЛИСТНЫЙ ИНТРОДУКЦИИ И СЕЛЕКЦИИ НИКИТСКОГО БОТАНИЧЕСКОГО САДА - НАЦИОНАЛЬНОГО НАУЧНОГО ЦЕНТРА
}

\section{Рецензент - доктор сельскохозяйственных наук Ю. В. Плугатарь}

\begin{abstract}
Створення декоративних форм, придатних для озеленення, особливо в сполученні з отриманням товарної продукиії високої якості досить актуальне. Персик червонолистий - изіний вихідний матеріал для селекиї декоративних форм. Він добре передає у спадок ознаку червоного забарвлення листя, шзо полегшує вирощування посадкового матеріалу декоративних червонолистих форм. Наведені результати вивчення помологічних якостей плодів вихідної батьківської форми інтродукованого персика червонолистого і його селекиійних форм. Показані їхні позитивні якості й можливість практичного використання в подальшій селекції та розсадництві в умовах Криму.
\end{abstract}

Ключевые слова: исходная форма, интродукция, селекиия, персик, питомниководство.

Постановка проблемы. Персик - одна из наиболее популярных южных культур. В южных областях Украины доминируют сорта селекции Государственного ботанического сада, более северных областях - сорта НИИ орошаемого садоводства УААН и Центрального ботанического сада НАНУ. В результате длительной культуры персика в различных природных условиях сложились эколого-географические группы культурных сортов с различным комплексом биологических и хозяйственных признаков и свойств. Основными из этих групп, по классификации И. Н. Рябова, являются северокитайская, южнокитайская, иранская и ферганская с соответствующими помологическими подгруппами: обыкновенные, хрящеватые, скороспелые, голоплодные и репчатые. Создание сортов с повышенной зимостойкостью важно для районов с неустойчивыми зимами, где вследствие резких колебаний температуры наблюдается массовая гибель цветковых почек [3].

Анализ основных исследований и публикаций по данной проблеме. Анализ многолетней динамики основных климатических показателей за 50 последних лет на метеорологической станции
Степного отделения Никитского ботанического сада показал, что климатические изменения, происходящие в этом регионе под влиянием глобальных процессов, изменяют условия произрастания плодовых культур. Эти изменения происходят не в лучшую сторону. Так, потепление зимнего периода влечет за собой резкие перепады от положительных значений к отрицательным и наоборот. Это значительно ухудшает условия перезимовки, провоцируя персик и другие южные культуры к значительным повреждениям цветковых почек, нередко приводя к полной их гибели. Период биологического покоя у них заканчивается к середине зимы [5].

Одним из путей повышения адаптационной способности персика в неблагоприятный зимний и зимне-весенний периоды является создание селекционным путем новых сортов с повышенной зимо- и морозостойкостью, что является весьма актуально для Крыма и других регионов юга Украины.

Наряду с совершенствованием персика обыкновенного, в селекционных программах Никитского ботанического сада предусмотрено создание декоративных форм, пригодных для озеленения, особенно в сочетании с получением товарной продукции с хорошим качеством плодов [3]. Ценным исходным материалом для селекции декоративных форм является персик краснолистный.

Формы персика краснолистного впервые в нашей стране были выявлены в Закарпатье, откуда они в 50-е годы завезены в Киев (ЦРБС АН УССР) и Никитский ботанический сад. Персик краснолистный хорошо передает по наследству признак красной окраски листьев. Это облегчает выращивание посадочного материала декоративных краснолистных форм [2].

Цель исследований. В условиях Крыма изучение особенностей биологии и селекционной ценности персика краснолистного ранее не проводили. В связи с этим нашими исследованиями

* Научный руководитель - доктор биологических наук Е. П. Шоферистов 
предусмотрено: изучить помологические качества интродуцированного персика Краснолистный и селекционные формы, созданные в Никитском ботаническом саду с его участием; определить перспективы дальнейшего использования элитных форм в условиях Крыма.

Методика проведения исследований. Исследования проведены в условиях южнобережной зоны Крыма на коллекционно-селекционных участках лаборатории южных плодовых культур Никитского ботанического сада. Растения выращены по общепринятой в Крыму для персика технологии. Методика изложена в приведенной литературе [3, 4].

Результаты исследований. По материалам последних лет первичного сортоизучения интродуцированного сорта персика Краснолистного (Persica vulgaris Mill. subsp. atropurpurea (Schneid.) Zajats) и селекционных форм, полученных на его основе, дана краткая помологическая характеристика. Ниже приводим их краткое описание.

Персик Краснолистный. Сорт интродукции Никитского ботанического сада. Плоды массой 53-85 г, округлой формы, вершина - округлая, слегка с углублением, основание округлое, с широким и глубоким углублением. Брюшной шов средний. Плодоножка - голая, к зрелому плоду прикреплена слабо. Плоды осыпаются при полном созревании. Опушение - среднее. Кожица с плода не снимается, средней толщины и плотности. Основная окраска - кремовая, покровная темно-розовая до карминовой, занимающая 75100 \% поверхности. Мякоть плода одноцветная с полостью - кремовая, средней хрящеватой консистенции, сочности, кислотности и плотности, средне темнеющая на воздухе. Аромат - средний. Вкус - содержательный (4,8 балла по 5-балльной шкале). Косточка - массой 6 г, не отделяется от мякоти, коричневая. Вкус семени горький. Созревает в 1-2-й декадах сентября.

Достоинства. Плоды пригодны для употребления в свежем виде, вывоза, изготовления компотов и варенья. Представляет интерес для теоретически-поисковых исследований как генетический маркер краснолистности, для изучения в качестве подвоя, константно воспроизводящего семенное потомство в садово-парковом строительстве на юге Крыма как декоративное растение для озеленение парков, бульваров, скверов.

Недостатки. Неотделяющаяся от мякоти косточка, простые пятилепестковые цветки.

Перспективы селекционного использования как исходная форма в гибридизации с персиком обыкновенным с медовым вкусом плодов, с сортами персика декоративного, отличающегося белыми, темно-красными, розовыми и пестрыми махровыми и полумахровыми цветками; нектарином, персиком карликовым, миндалем обыкновенным для создания краснолистных подвоев.

Персик Краснолистный 27-03. Перспективная форма селекции Никитского ботанического сада. Плоды - массой 54-78 г, округлой формы, вершина - округлая, основание - округлое с углублением. Брюшной шов - средний. Плодоножка голая, к зрелому плоду прикреплена слабо. Опушение - среднее. Кожица с плода снимается с трудом, средней толщины и плотности. Основная окраска - желтая, покровная - карминовая, занимающая 75-100\% поверхности. Мякоть плода - желтая, полость одноцветная с мякотью, средней волокнистой консистенции и плотности, на воздухе не темнеет. Сочность - средняя, кислотность и аромат - слабые. Вкус - содержательный (4,5 балла), превалирует слабо сахар. Косточка - массой 4,2 г, средне отделяется от мякоти, коричневая. Вкус семени - горький. Созревает в третьей декаде августа - первой декаде сентября.

Достоинства. Плоды пригодны для употребления в свежем виде, вывоза, изготовления компотов и варенья. Представляет интерес для изучения в качестве семенного подвоя для косточковых культур и как исходная родительская форма для дальнейшей селекционной работы.

Недостатки. Не очень крупные плоды.

Персик Краснолистный 296-73. Селекционная форма выделенная в НБС-ННЦ. Плоды - массой 65-90 г, плоско-округлой формы, вершина округлая, основание - округлое с глубоким углублением. Брюшной шов - средний. Плодоножка голая, к зрелому плоду прикреплена слабо. Опушение - среднее. Кожица с плода не снимается, средней толщины и плотности. Основная окраска - кремовая, покровная - карминовая, занимающая 75 \% поверхности. Мякоть плода одноцветная с полостью, кремовая, средней волокнистой консистенции и плотности, средне темнеющая на воздухе. Сочность, кислотность, сахаристость и аромат - средние. Вкус - удовлетворительный (3,5 балла). Косточка - массой 7,0 г, не отделяется от мякоти, коричневая. Вкус семени - горький. Созревает в третьей декаде сентября - первой декаде октября.

Достоинства. Плоды пригодны для употребления в свежем виде и технологической переработки. Представляет интерес как декоративное краснолистное растение. Может быть использован в селекции как источник позднего срока созревания, характеризующийся краснолистностью.

Выделены интересные селекционные идентичные краснолистные корнесобственные формы персика: 3-10-30, 3-10-33, 3-10-37, 3-10-38 и 
3-10-39. Все они медового вкуса, типа персика Хони (Honey), с белой окраской мякоти плодов, созревают во второй декаде сентября. Аналоги персика краснолистного с медовым вкусом плодов в отечественной сельскохозяйственной литературе отсутствуют.

Имеются зарубежные сорта персика зеленолистного, характеризующиеся сладкой мякотью с медовым привкусом, которые культивируют в провинциях Китая Цзянсу и Чшэн-цзяу: Шанхай-Шуй-Ми, Бай-Ман-Шуй-Ми, Цзы-Ян-ШуйМи и др. [1]. Ниже приводим помологическую характеристику одной из форм персика краснолистного с медовым вкусом плодов.

Персик Краснолистный 3-10-30. Плоды - массой 70-82 г, округло-овальной формы, вершина округло-вдавленная, основание - притупленное с глубоким углублением. Брюшной шов - средний. Плодоножка - голая, к зрелому плоду прикреплена слабо. Опушение - слабое. Кожица с плода не снимается, тонкая и средней плотности. Основная окраска - белая, покровная - карминовая с мраморовидным рисунком, занимающая всю поверхность. Мякоть плода - белая, полость возле косточки слегка розовая, средней волокнистой консистенции, сочности, аромата и плотности, не темнеет на воздухе. Вкус содержательный $-4,5$ балла. Косточка - массой 6,0 г, отделяется от мякоти хорошо, коричнево-малиновая. Вкус семени - горький. Созревает в первой декаде сентября.

Достоинства. Плоды пригодны для употребления в свежем виде, вывоза, изготовления компотов и варенья, замораживания. Представляет интерес для селекции как источник генетически маркерного признака - медового вкуса.

Перспективы практического использования. На примере описанных форм персика краснолистного с медовым вкусом плодов можно прогнозировать создание на их генетической основе селекционным путем еще неизвестных в плодоводстве аналогов в системе различных таксонов рода Persica.

Выделены нами также из гибридного фонда оригинальные корнесобственные краснолистные формы персика с простыми пятилепестковыми цветками розовой окраски: 131-00, 233-00, 277-00,

\section{БИБЛИОГРАФИЯ}

1. Витковский В. Л. Персик / В. Л. Витковский / Плодовые растения мира. - СПб. : Лань, 2003. C. 139-160.

2. Заяць В. A. Персик у Карпатах / В. А. Заяць. Ужгород : Карпаты, 1988. - 127 с.

3. Интенсификация селекции плодовых культур / под ред. В. К. Смыкова, А. И. Лищука. - Ялта, 1999. - Т. 118. - 216 с.

4. Программа и методика сортоизучения плодо- а также созданные краснолистные генотипы с полумахровыми розовыми цветками: 235-00, 239-00, 240-00 и 244-00. Помологические признаки у выделенных форм очень близки. В связи с этим описание плодов приводим лишь одной из упомянутых форм, отличающейся красивыми полумахровыми розовыми цветками.

Персик Краснолистный 240-00. Плоды - массой 71-75 г, округлой формы, вершина - выдавленная, основание - притупленное. Брюшной шов - слабый. Плодоножка - голая, к зрелому плоду прикреплена в средней степени. Опушение - слабое. Кожица с плода снимается легко, средней толщины и плотности. Основная окраска - кремово-желтая, покровная - карминовая, занимающая 10 \% поверхности. Мякоть плода кремово-желтая, полость - розовая, средней волокнистой консистенции и плотности, средне темнеет на воздухе. Сочность, кислотность и аромат - средние. Вкус - содержательный (4,0 балла), средне превалирует кислота. Косточка массой 5,4 г, хорошо отделяется от мякоти, темно-коричневая. Вкус семени - горький. Созревает в третьей декаде августа - первой декаде сентября.

Достоинства. Плоды пригодны для употребления в свежем виде. Представляет интерес для дальнейшей селекционной работы с различными таксонами рода Persica.

Выводы: 1. Плоды всех выделенных перс пективных селекционных форм персика краснолистного пригодны для употребления в свежем виде и технологической переработки. Персик Краснолистный 27-03 представляет интересс для изучения в качестве семенного подвоя косточковых культур.

2. Персик Краснолистный 3-10-30 является источником генетически ценных признаков - белая окраска мякоти плодов, медового вкуса и краснолистности. Он рекомендован нами для широкого использования в селекции со всеми известными таксонами рода Persica Mill.

3. Персик Краснолистный 240-00 с полумахровыми розовыми цветками рекомендуем использовать для совершенствования всех декоративных зеленолистных форм персика с махровыми цветками.

вых, ягодных и орехоплодных культур / под ред. Е. Н. Седова, Т.П. Огольцовой. - Орел : ВНИИСПК, 1999. - 608 с.

5. Рябов B. A. Влияние глобального потепления на местный климат и возможные последствия для плодовых культур / В. А. Рябов // Наукові праці ПФ НУБіП України «КАТУ», 2011. Вип. 137. - С. 127-137. 